\title{
Construction and Management Plan of Constructed Wetland for Promoting Biodiversity
}

\author{
Soon-Hyoung Bae ${ }^{1,2}$ and Soo-Dong Lee ${ }^{2}$ * \\ ${ }^{1}$ Korean Environmental Preservation Association, Changwon 51430, South Korea \\ ${ }^{2}$ Department of Landscape Architecture, Gyeongnam National University of Science and Technology, Jinju 52725, South Korea
}

\begin{abstract}
This study was carried out to propose the creation and management method in the constructed wetland through the monitoring physical environments with different sizes, shapes, water depths, vegetation and fauna. The biota was investigated and analyzed according to the time series changes of the wetland that was classified by location type, depth of water, and surrounding environmental condition. As a result of the biota monitoring, the constructed wetlands surrounded by various ecosystems such as forests, agricultural lands, etc. had higher species diversity than other types of wetlands. However, the water surface area of the wetland with a shallow depth was decreased due to widening Phragmites communis, Typha orientalis, and naturally infused Leersia japonica. This resulted in a decrease in the number of wetland dependent species like dragonflies, rather than external habitat species like wild birds and butterflies. Therefore, in order to restore the wetland in the future, it is necessary to select the preferable location and maintain the water surface by controlling water depth. In terms of site selection, it is essential to select sites where natural ecosystems can come in contact with various ecosystems for the influx of species from the outside. Regarding the water depth, it is desirable to keep less than $1 \mathrm{~m}(0.1 \sim 0.5 \mathrm{~m})$ for various vegetation distributions and at least 1 2 $\mathrm{m}$ to maintain the water surface. In addition, long-term monitoring and management are required for the self-sustaining of wetlands and various ecological functions. Based on this, management for water depth adjustment and inhibition of vegetation propagation should be necessary to maintain open water level.
\end{abstract}

Keywords: open water, species diversity, time sequential change, wetland management

\section{Introduction}

A wetland is a transition area between terrestrial and aquatic ecosystem that maintains an humid condition either permanently or temporarily or seasonally, and has high biodiversity (Cowardin et al., 1979; Cylinder et al., 1995). Wetlands are abundant with water regardless of running water, standing water, fresh water, seawater, brackish water, etc., and they themselves are a land that forms a society with various plant and animal species (Zhu and Koo, 2006). Wetlands, as a rich and productive repository of various biological resources, are essential spaces for the survival of not only humans but also various flora and fauna. They play multiple roles in ecosystems such supplying and storing seeds and materials,

This study was conducted as part of the Project for the Ecological Belts in the Nakdong River Basin.

Received: April 10, 2018, Revised: April 13, 2018, Accepted: May 18, 2018

First author: Soon-Hyoung Bae, E-mail: nucle99@naver.com, ORCID: 0000-0003-1571-1422

*Corresponding author: Soo-Dong Lee, E-mail: ecoplan@gntech.ac.kr, ORCID: 0000-0003-4893-8850 
and exchanging nutrients and carbon (Mitsch and Gossenlink, 2000, 2007), and these functions are extensively applied in order to improve water quality in natural or constructed wetlands (Brix, 1997). However, due to the activities of humans and climate change, about $50 \%$ of the total wetlands disappeared in the last century, and without any improvement in the current status, a damaged areas will continue to increase (Houghton et al., 2001; Jones et al., 2009). Reclamation, drainage and cultivation can destroy wetlands, which results in a decrease in the diversity of wild animals and plants that live in wetlands and thus raises people's interest in the conservation, restoration and creation of wetlands both in Korea and around the world.

Constructed wetlands are known to restore not only functions such as treating agricultural water, storing nitrogen, treating polluted water, etc. but also damaged biodiversity by providing habitat for wildlife (Rousseau et al., 2008; Keenleyside et al., 2012). According to the Hiraishi et al. (2014), a constructed wetland is a wetland that is designed and constructed to contain vegetation, soil, microbial communities, etc. for treating wastewater and to utilize natural processes. Constructed wetlands are divided into two types: surface flow and subsurface flow. Since constructed wetlands have functions such as improving water quality, detaining flood water, separating and treating rainfall and surface runoff water and circulating nutrients and other substances, the number and areas are expected to increase (DuPoldt et al., 2015). In addition, they are in general constructed by modelling natural structures of soil, biota and plants that live in natural wetlands in order to promote hydrologic, physical, chemical and biological processes (Moat et al., 2008). In Korea, studies have been conducted mainly on the effects of wetlands on the reduction of nonpoint pollutants (Kim et al., 2008; Lee et al., 2014: Moon at al., 2014; Kim, 2010) and the reduction of domestic sewage, livestock wastewater and pollutants (Seo, 2014; Kim et al., 2012), but no study on biodiversity (Kim and Cho, 1999) has been conducted entering the 2000s. Various studies have been carried out on wetlands so far, but it is still necessary to verify the effects of constructed wetlands on promoting biodiversity, and to review practical management measures.

Meanwhile, the Korean government has designated and purchased the areas that are within $0.5 \sim 1 \mathrm{~km}$ from river and lake boundaries as a riparian buffer zone for improving the water quality of the four major rivers since 2003 (Act on Water Management and Residents Support in the Nakdong River Basin, Article 4-3, Enforcement Decree Article 5-2). In the purchased land, ecological belts have been constructed in order to treat point and nonpoint pollutants by restoring wetlands and vegetation. Sources of pollutants that directly affect the water quality management of water supply sources such as factories, cattle sheds and restaurants have been purchased to create green spaces as a buffer area and treat pollutants (Ministry of Environment, 2012). So far, approximately $14.5 \mathrm{~km}^{2}$ of land has been purchased, and $41.4 \%(6.0$ $\mathrm{km}^{2}$ ) of the land was turned into constructed wetlands and vegetation restored areas, which is expected to improve water quality and biodiversity (Ministry of Environment, 2018). Against this backdrop, this study monitored the physical environments and fauna of constructed wetlands with different sizes, shapes, water depths and plant coverage ratios in Sancheong-gun, Korea, and suggested measures to create and manage constructed wetlands for maintaining biodiversity.

\section{Materials and Methods}

\section{Scope and procedures}

Within the riparian buffer zones in Sancheong-gun, Korea that had been purchased from 2003 to 2012, a total of 33 wetlands were constructed to reduce point and nonpoint pollution sources (Internal documents of the Korean Environmental Preservation Association, 2017). Out of the constructed wetlands, 7 wetlands of which water surface has been well maintained throughout a year and that can provide habitat for wetland dependent and using species were monitored to examine the trend of changes in biodiversity. It might be reasonable to select and survey constructed wetlands in various 
regions. In this study, however, constructed wetlands in only one administrative district were targeted, since it is possible to compare biotas only when the same conditions for climate, vegetation, etc. are guaranteed. Based on the data, this study examined trends of increasing or decreasing biodiversity over time after constructing wetlands, and suggested measures to create and manage constructed wetlands.

Figure 1 shows the location of the 7 wetlands constructed in Danseong-myeon, Sancheong-gun, and the land used to be agricultural land such as fields and paddies in the past, and was purchased and restored to wetlands. The types of the constructed wetlands were divided based on elements that affect the habitation of aquatic life such as water depth, shape, surrounding environment, etc. (van der Valk, 2012). In terms of water depth, among wetlands that have a similar shape, the wetland of which maximum water depth is over $1 \mathrm{~m}$ was categorized as deep water type, and the one of which average water depth is around $0.5 \mathrm{~m}$ and $0.2 \mathrm{~m}$ was categorized as medium and shallow water types respectively. In terms of structural shape, the constructed wetlands were divided into pool type that has water surface, but non-cultivated type that hasn't (Table 1). Those that are surrounded by various ecosystems have high diversity potential as wildlife can be naturally introduced to the wetlands (Weller, 1999), and thus the constructed wetlands were divided into a total of 6 types including 2 ecotone types considering surrounding environments.

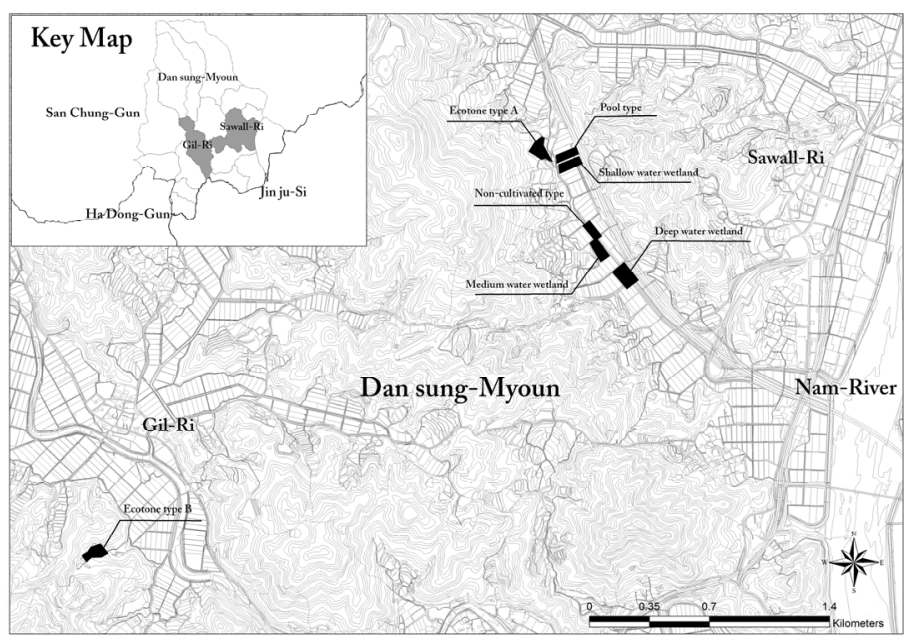

Figure 1. Location map of constructed wetlands in Dansung-myeon Sancheong-gun, Korea.

Table 1. General status and land use before construction of each constructed wetland

\begin{tabular}{|c|c|c|c|c|c|c|c|}
\hline & \multirow{2}{*}{ Wetland type } & \multirow{2}{*}{$\begin{array}{l}\text { Location (Danseung-myeon, } \\
\text { Sancheong-gun) }\end{array}$} & \multirow{2}{*}{$\begin{array}{l}\text { Land use before } \\
\text { restoration }\end{array}$} & \multirow{2}{*}{$\begin{array}{c}\text { Construction } \\
\text { year }\end{array}$} & \multirow{2}{*}{$\begin{array}{l}\text { Area } \\
\left(\mathrm{m}^{2}\right)\end{array}$} & \multicolumn{2}{|c|}{ Water depth $(\mathrm{cm})$} \\
\hline & & & & & & Minimum & Maximum \\
\hline \multirow{3}{*}{ Water depth } & Deep water wetland & Sawall-ri 403 & Rice paddy & 2010 & 5,189 & 5.3 & 111.1 \\
\hline & Medium water wetland & Sawall-ri 332 & Rice paddy & 2010 & 2,712 & 23 & 43.3 \\
\hline & Shallow water wetland & Sawall-ri 257 & Rice paddy & 2010 & 2,662 & 11.5 & 35 \\
\hline \multirow{2}{*}{$\begin{array}{l}\text { Structural } \\
\text { shape }\end{array}$} & Non-cultivated type & Sawall-ri 317 & Rice paddy & 2010 & 2,701 & 4 & 12 \\
\hline & Pool type & Sawall-ri 232 & Rice paddy & 2012 & 2,873 & 5 & 59 \\
\hline \multirow{2}{*}{$\begin{array}{l}\text { Surrounding } \\
\text { environment }\end{array}$} & Ecotone type A & Sawall-ri 1271-2 & Rice paddy & 2007 & 9,209 & 1 & 58 \\
\hline & Ecotone type B & Gil-ri 811 & Barn & 2009 & 4,744 & 1.5 & 13.5 \\
\hline
\end{tabular}




\section{Procedures and methods}

With the purpose of preventing water pollution caused by point and nonpoint pollution sources located near rivers, this study was conducted following the three stages: surveying and analyzing the physical environments and ecological characteristics of the constructed wetlands; assessing biodiversity; and suggesting measures to create and manage wetlands (Table 2). In the first stage for surveying and analyzing physical environments and ecological characteristics, surrounding environments that affect the habitation of animals and plants, and physical structures and shapes were surveyed. In this stage, physical characteristics such as water depth and surrounding land use, and ecological characteristics such as the existing vegetation and wild animals were surveyed in order to identify trends of changes over time. In the second stage, biodiversity was also compared to analyze the effects of physical and environmental changes over time. To analyze changes in the composition of fauna depending on time-series changes, fauna that were observed in 2012 and 2015 were compared and analyzed. For the analysis of biodiversity, species diversity and richness were compared, and the effects of the decreasing area of water surface caused by increasing vegetation on biotas were compared and analyzed. In the third stage for suggesting measures to create and manage wetlands for the promotion of biodiversity, the potential of wetlands was confirmed based on the results, and measures were suggested to create and manage wetlands and thus to promote biodiversity.

In this study, physical environments and ecological characteristics were surveyed and analyzed, and time series changes in biodiversity were examined based on the surveyed data. Measures to create and manage wetlands for the promotion of biodiversity were suggested based on the results. In the process of surveying and analyzing physical environments and ecological characteristics, aerial photographs were utilized to identify the locational relationships of constructed wetlands with roads, forests and rivers and their locational characteristics and surrounding land use. The land cover of surrounding areas was surveyed in detail through on-site surveys, and using the map service of Daum (http://map.daum.net), the maps of the areas from 2008 until now were compared and analyzed. Time differences between aerial photographs and surveys are attributable to the timing of updates, which does not seem to affect analyzing trends of changes. Water depth was measured by installing a post attached with a tapeline within wetlands. The current vegetation was surveyed on site using $1 / 5,000$ scale maps, and the range of vegetation was mapped based on the vegetational physiognomy of prevalent wetland

Table 2. Research item and contents for biodiversity comparison in constructed wetlands

\begin{tabular}{|c|c|c|}
\hline \multicolumn{2}{|c|}{ Research item } & Contents \\
\hline \multirow{2}{*}{$\begin{array}{l}\text { Step 1: } \\
\text { Physical and ecological } \\
\text { characteristic analysis }\end{array}$} & Wetland type classification & $\begin{array}{l}\text { Vegetation, environmental characteristics of surrounding area, } \\
\text { classification wetland types by depth }\end{array}$ \\
\hline & $\begin{array}{l}\text { Physical and ecosystem } \\
\text { characteristic analysis }\end{array}$ & $\begin{array}{l}\text { - Physical characteristic: Location, Status, Depth } \\
\text { - Ecosystem characteristic: Vegetation area (open water area), Species } \\
\text { (mammalia, wildbird, herptile, butterfly, dragonfly) }\end{array}$ \\
\hline \multirow[b]{2}{*}{$\begin{array}{l}\text { Step 2: } \\
\text { Biodiversity analysis }\end{array}$} & Biodiversity analysis & - Biodiversity by wetland type, species diversity and richness \\
\hline & $\begin{array}{l}\text { Changes in biodiversity due to } \\
\text { ecosystem changes }\end{array}$ & $\begin{array}{l}\text { - Decrease in open water area due to increase of internal vegetation of } \\
\text { wetland } \\
\text { - Analysis of biodiversity change due to decrease of vegetation and open } \\
\text { water }\end{array}$ \\
\hline \multicolumn{2}{|c|}{$\begin{array}{l}\text { Step 3: Suggestion of construction and the management plan } \\
\text { in the constructed wetlands for increase of biodiversity }\end{array}$} & $\begin{array}{l}\text { - Propose the wetland construction method through the biodiversity } \\
\text { evaluation } \\
\text { - Suggest the management plan based on time series changes of } \\
\text { constructed wetlands }\end{array}$ \\
\hline
\end{tabular}


species. In particular, to analyze the ratio of water surface, although the same species are prevalent, constructed wetlands were segmented depending on whether water surface was included or not, and the size and ratio of each type were calculated, comparing and analyzing the time of construction (2012) and after the construction (2015).

Fauna that were surveyed in this study include wild birds, herptiles, butterflies and dragonflies, and species that appeared within the wetlands and in their surrounding areas at the time of construction (2012) and after the construction (2015) were observed and recorded every two weeks from April to December in order to compare changes in biodiversity over time. The species that appeared along the ridges between rice paddies or watersides across all the target areas were listed and their population was surveyed. To survey the habitation of wild birds, the number and population of species that appeared across all the target areas were observed with the naked eyes and using binoculars by changing the timing of observation by season in consideration of the results of the study of Kim et al. (2013), and their sounds and flying were also observed. In the case of amphibians, the water surface of the wetlands was surveyed between late February and early March in order to check whether they laid eggs or not, and after that the species that lived in the wetlands were collected and recorded using insect nets and skimming nets. In the case of reptiles, the inside of the wetlands and the soil below stones near the wetlands were surveyed and reptiles were collected using snake tongs and insect nets. The species observed on site were photographed and recorded on a field note, and their species were identified based on Kang and Yoon (1975) and Yang et al. (2001). Dragonflies, a wetland dependent species, live in the water or near the water during their imaginal and larval stages, and water surface is very important for them to find preys and lay eggs (Cho, 2013). Thus, it is essential to observe dragon flies as an indicator species that plays an important part in the food chain of aquatic ecosystems (Koo and Sim, 1997) in identifying changes in fauna in the wetland ecosystem. The name and population of the imagoes of dragonflies that flew or stood still for about 10 minutes within each surveyed zone were recorded. Butterflies were observed with the naked eyes, and those of which name was difficult to identify with the naked eyes were collected using a net (diameter $40 \mathrm{~cm}$ ), and their species were identified. They were classified and identified based on the criteria suggested by Jung (2007).

In the stage of comparing biodiversity, the level of biodiversity within the target wetlands was surveyed by comparing and analyzing the number, population and diversity of species. The diversity of and the time series changes in the surveyed fauna were analyzed using the index of Shannon diversity $\left(\mathrm{H}^{\prime}\right)$ that was suggested by Shannon and Weaver (1949) and focused on rare species.

In the stage of suggesting measures to create and manage wetlands for the promotion of biodiversity, changes in the biodiversity of the target wetlands were examined depending on biological and physical changes in vegetation, water surface, etc. that were found through assessment. Based on changes in physical environments and ecological conditions that were observed after constructing wetlands, measures to create and manage wetlands for the promotion of biodiversity were suggested in this study.

\section{Results and Discussion}

\section{Physical environments and ecological characteristics}

\section{Changes in the characteristics of vegetation and land cover}

Table 3 and Figure 2 shows the comprehensive results of the ecological characteristics of each wetland type, and the results were analyzed by focusing on changes in the area of water surface which was suggested as a factor that affects species diversity (Weller, 1999). The water surface of deep, medium and shallow water wetlands was reduced from $25.5 \%, 36.2 \%$ and $15.5 \%$ in 2012 to $11.9 \%, 19.4 \%$ and $0.9 \%$ in 2015 . The results can be attributed to, in the case of the 
Table 3. Changes in the actual vegetation and water surface

\begin{tabular}{|c|c|c|c|c|c|c|c|c|c|c|c|c|c|c|c|}
\hline \multirow[t]{2}{*}{ Classification } & \multirow[t]{2}{*}{ Legend } & \multicolumn{2}{|c|}{$\begin{array}{l}\text { Deep water } \\
\text { wetland }\end{array}$} & \multicolumn{2}{|c|}{$\begin{array}{l}\text { Medium water } \\
\text { wetland }\end{array}$} & \multicolumn{2}{|c|}{$\begin{array}{l}\text { Shallow water } \\
\text { wetland }\end{array}$} & \multicolumn{2}{|c|}{$\begin{array}{l}\text { Non-cultivated } \\
\text { type }\end{array}$} & \multicolumn{2}{|c|}{ Pool type } & \multicolumn{2}{|c|}{$\begin{array}{l}\text { Ecotone } \\
\text { type A }\end{array}$} & \multicolumn{2}{|c|}{$\begin{array}{l}\text { Ecotone } \\
\text { type B }\end{array}$} \\
\hline & & 2012 & 2015 & 2012 & 2015 & 2012 & 2015 & 2012 & 2015 & 2012 & 2015 & 2012 & 2015 & 2012 & 2015 \\
\hline \multirow{2}{*}{ Open water } & Area $\left(\mathrm{m}^{2}\right)$ & $1,324.3$ & 617.8 & 982.1 & 525.3 & 411.9 & 24.0 & - & 418.1 & 329.6 & $1,023.2$ & 234.8 & 99.0 & 195.0 & 154.7 \\
\hline & Percent (\%) & 25.5 & 11.9 & 36.2 & 19.4 & 15.5 & 0.9 & - & 15.4 & 6.8 & 35.6 & 7.2 & 3.0 & 2.9 & 2.3 \\
\hline \multirow{2}{*}{$\begin{array}{l}\text { Typha } \\
\text { orientalis }\end{array}$} & Area $\left(\mathrm{m}^{2}\right)$ & 626.7 & 541.4 & 595.3 & 530.9 & 352.4 & 156.5 & $2,302.1$ & - & - & 760.7 & - & - & 83.5 & 360.9 \\
\hline & Percent (\%) & 12.1 & 10.4 & 22.0 & 19.6 & 13.2 & 5.9 & 85.2 & - & - & 26.5 & - & - & 1.2 & 5.3 \\
\hline \multirow{2}{*}{$\begin{array}{l}\text { Phragmites } \\
\text { spp. }\end{array}$} & Area $\left(\mathrm{m}^{2}\right)$ & 128.5 & 669.5 & 0.0 & 115.1 & - & - & - & - & - & - & $1,638.6$ & $2,234.8$ & 318.2 & 411.0 \\
\hline & Percent (\%) & 2.5 & 12.9 & 0.0 & 4.2 & - & - & - & - & - & - & 50.2 & 68.5 & 4.7 & 6.1 \\
\hline \multirow{2}{*}{ Hydrophytes } & Area $\left(\mathrm{m}^{2}\right)$ & $1,107.3$ & $1,460.1$ & 180.3 & 210.9 & - & 515.2 & - & $1,757.5$ & 132.0 & 197.2 & $1,154.8$ & 927.3 & $1,623.7$ & $1,332.9$ \\
\hline & Percent (\%) & 21.3 & 28.1 & 6.6 & 7.8 & - & 19.4 & - & 65.2 & 3.3 & 6.9 & 35.4 & 28.4 & 24.0 & 19.7 \\
\hline \multirow{2}{*}{ Mesophytes } & Area $\left(\mathrm{m}^{2}\right)$ & $2,002.1$ & $1,781.0$ & 954.3 & 837.4 & $1,897.7$ & $1,966.3$ & - & - & $2,920.2$ & 892.0 & 232.8 & 0.0 & 950.2 & 989.4 \\
\hline & Percent (\%) & 38.6 & 34.3 & 35.2 & 30.9 & 71.3 & 73.9 & - & - & 90.0 & 31.0 & 7.1 & 0.0 & 14.1 & 14.6 \\
\hline \multirow{2}{*}{ etc. } & Area $\left(\mathrm{m}^{2}\right)$ & - & 119.3 & - & - & - & - & 398.9 & 525.4 & - & - & - & - & $1,573.2$ & $1,495.3$ \\
\hline & Percent (\%) & - & 2.3 & - & - & - & - & 14.8 & 19.5 & - & - & - & - & 23.3 & 22.1 \\
\hline
\end{tabular}

Note. Phragmites spp.=Phragmites communis, Phragmites japonica; Hydrophytes=Juncus effusus var. decipiens, Iris sanguinea, Acorus calamus var. angustatus, Schoenoplectus triqueter, Leersia japonica, Caltha palustris; Mesophytes=Artemisia princeps, Setaria viridis, Rumex crispus, Miscanthus sacchariflorus; etc.=Rosa multiflora, Reynoutria japonica, Salix gracilistyla.

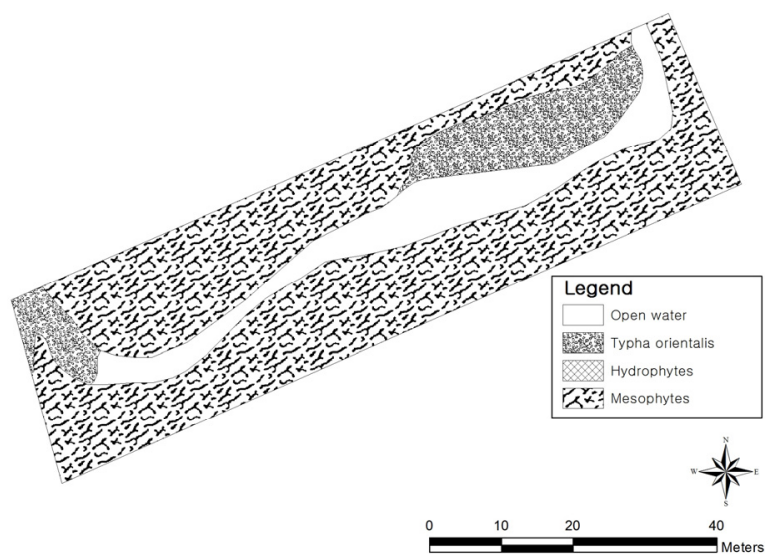

Shallow water wetland 2012

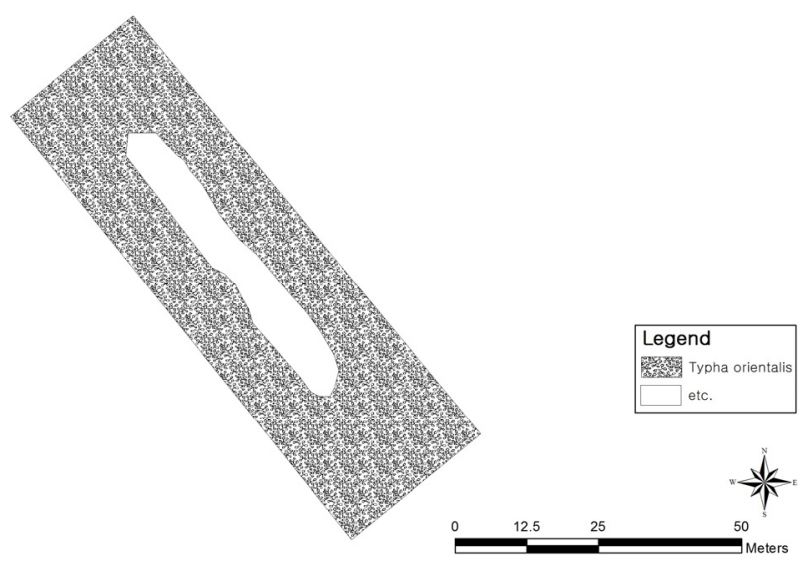

Non-cultivated type 2012

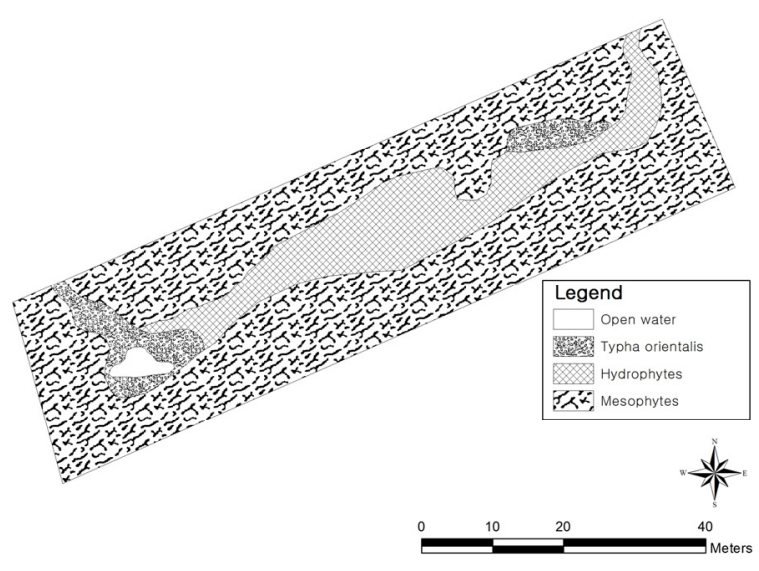

Shallow water wetland 2015

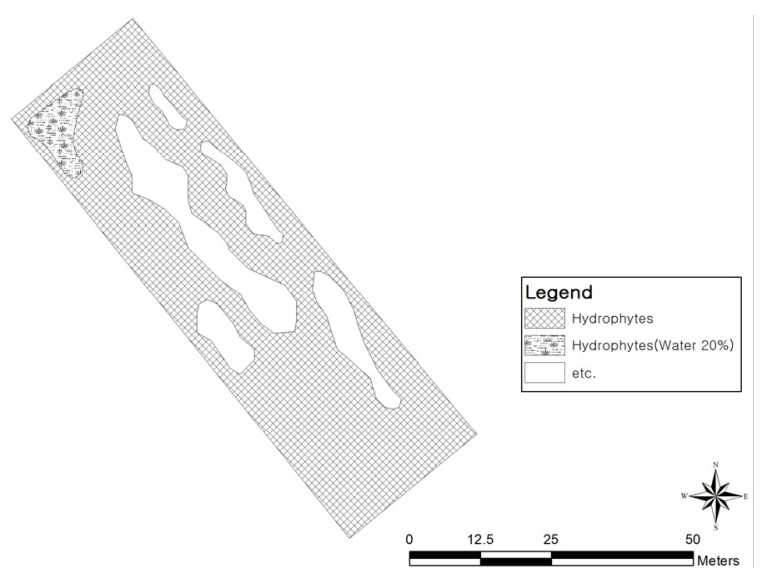

Non-cultivated type 2015

Figure 2. Actual vegetation map by wetland type in 2012 and 2015. 


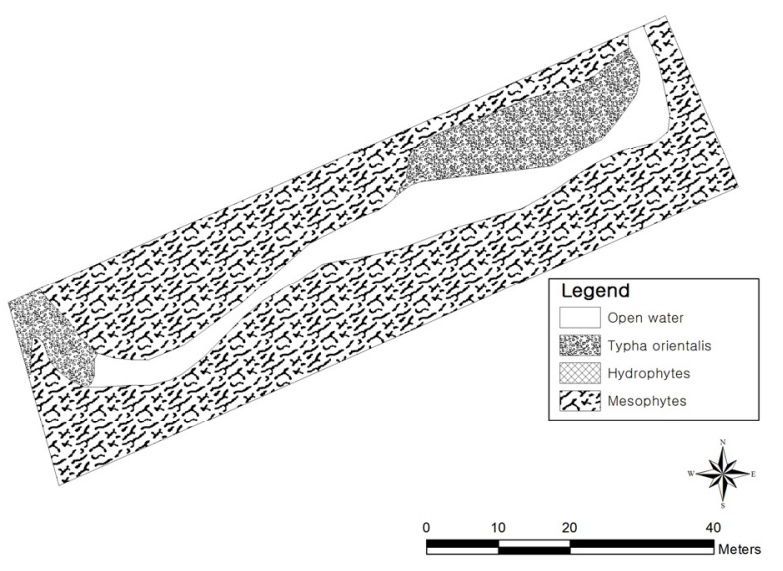

Shallow water wetland 2012

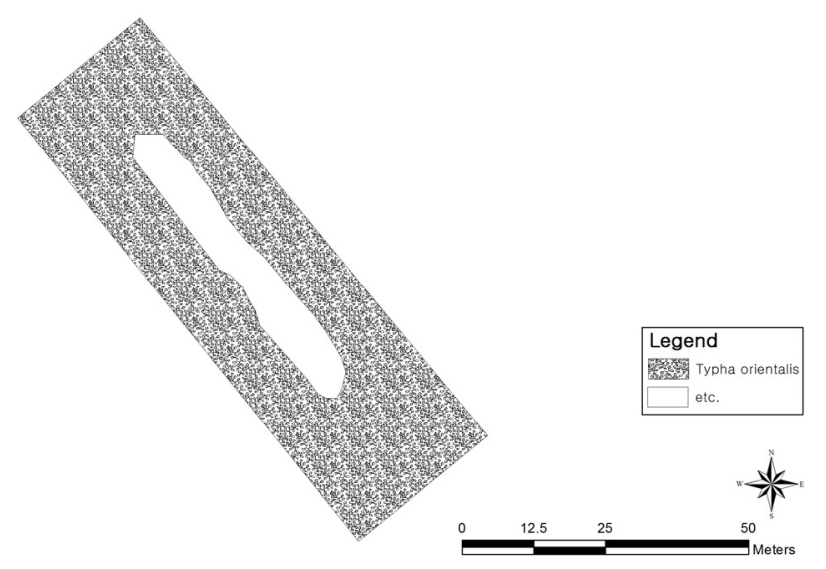

Non-cultivated type 2012

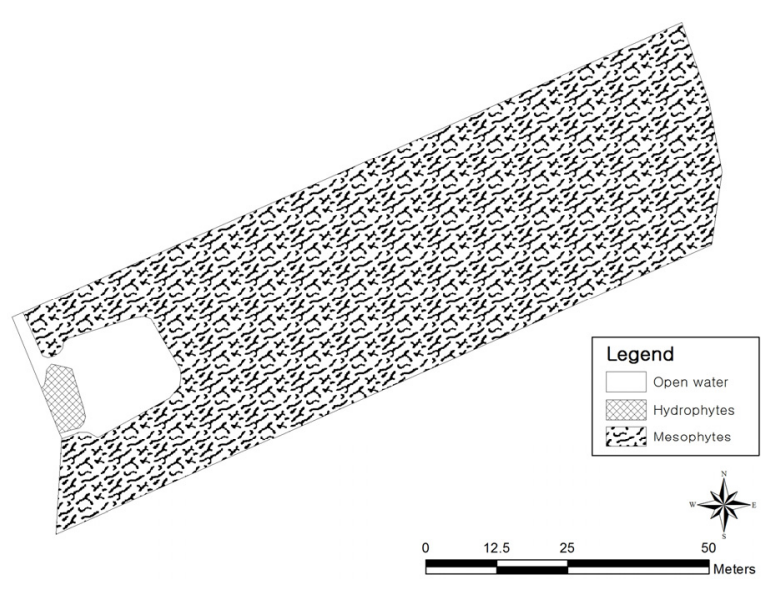

Pool type 2012

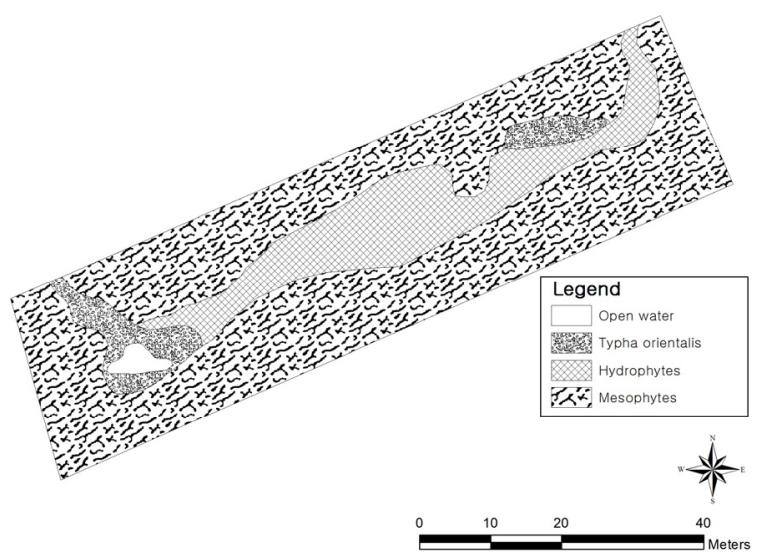

Shallow water wetland 2015

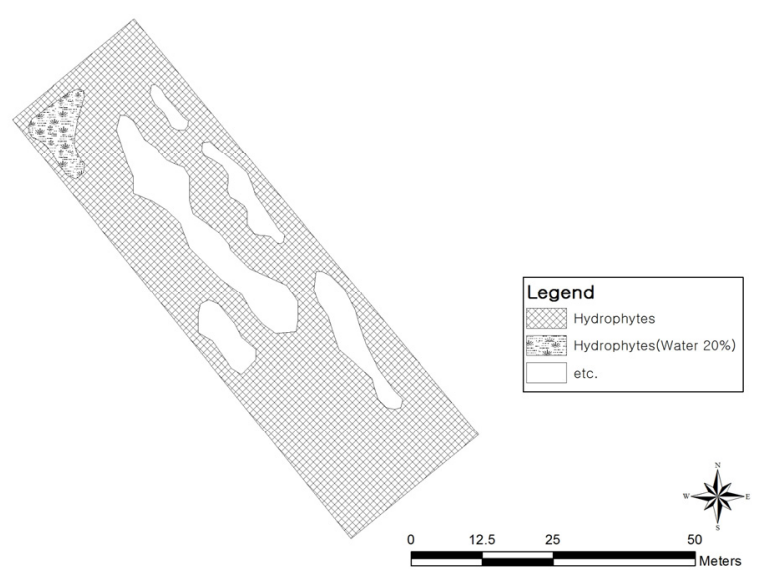

Non-cultivated type 2015

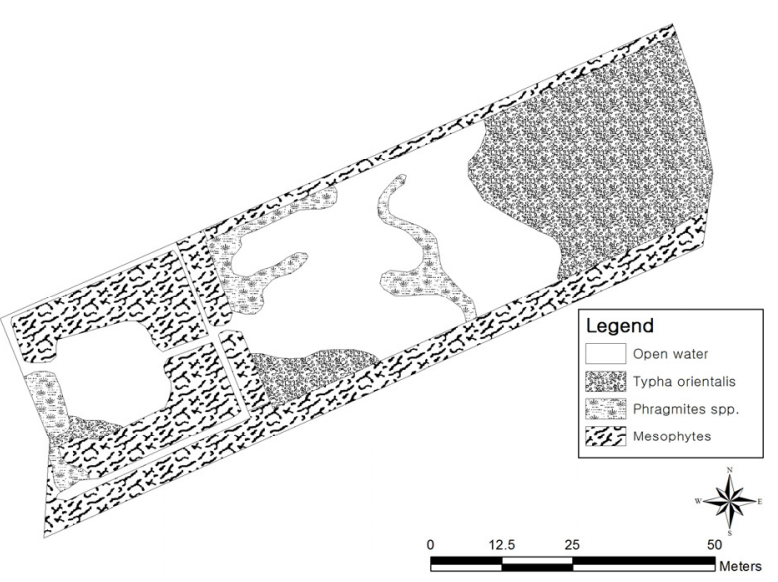

Pool type 2015

Figure 2. Actual vegetation map by wetland type in 2012 and 2015. (Continued)

deep water wetland, Phragmites australis, Phragmites japonica S. and Typha orientalis that covered its shallow area, and, in the case of medium and shallow water wetlands, Leersia Japonica that was not originally planted but naturally grew and covered its shallow area. The water surface of the non-cultivated and pool type wetlands increased from $0 \%$ and $6.8 \%$ to $15.4 \%$ and $35.6 \%$ due to natural disturbance and artificial management. There was no change in vegetation in the non-cultivated wetland as it was managed through activities such as mowing, etc., but when it rained, water surface was 


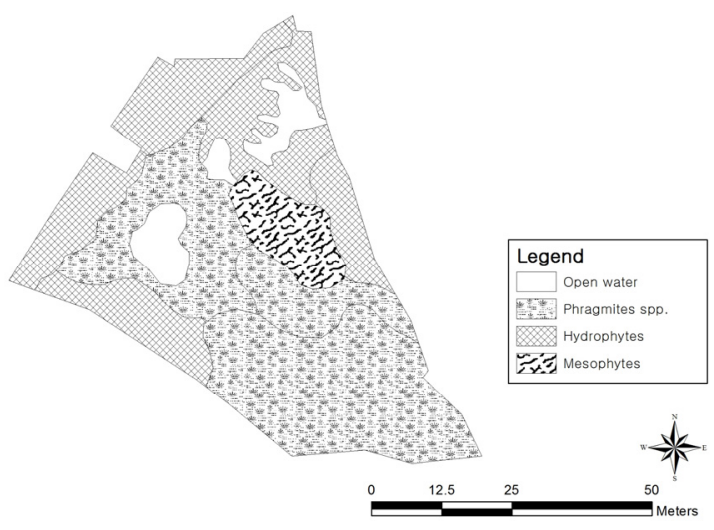

Ecotone type A 2012

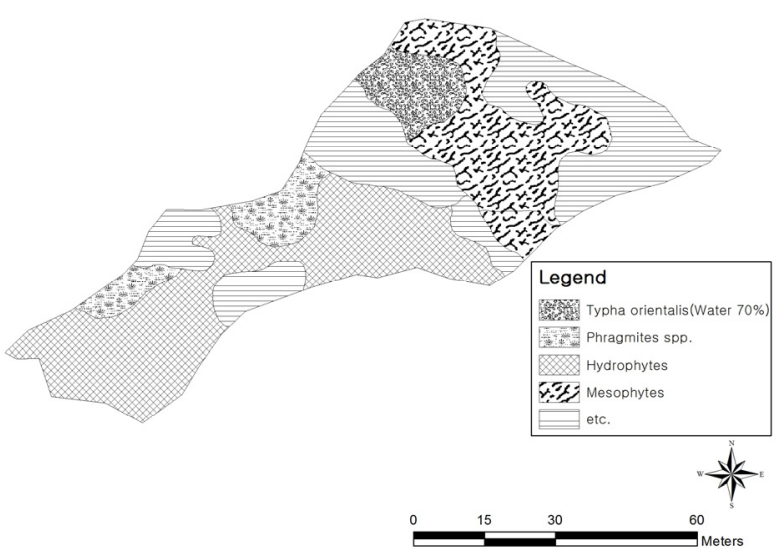

Ecotone type B 2012

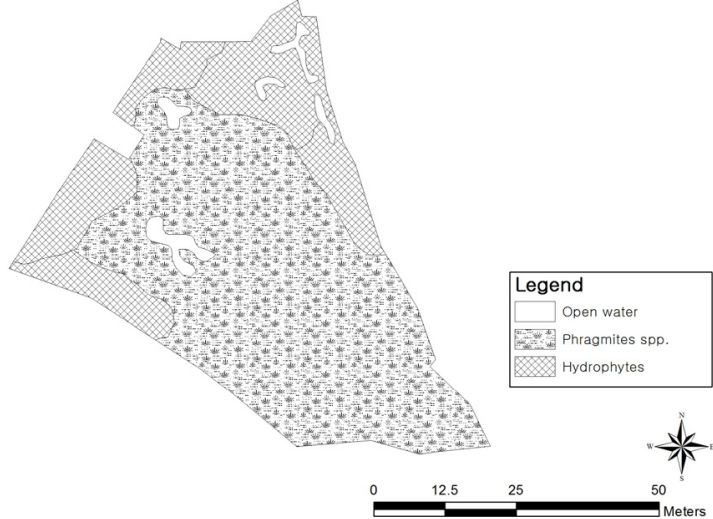

Ecotone type A 2015

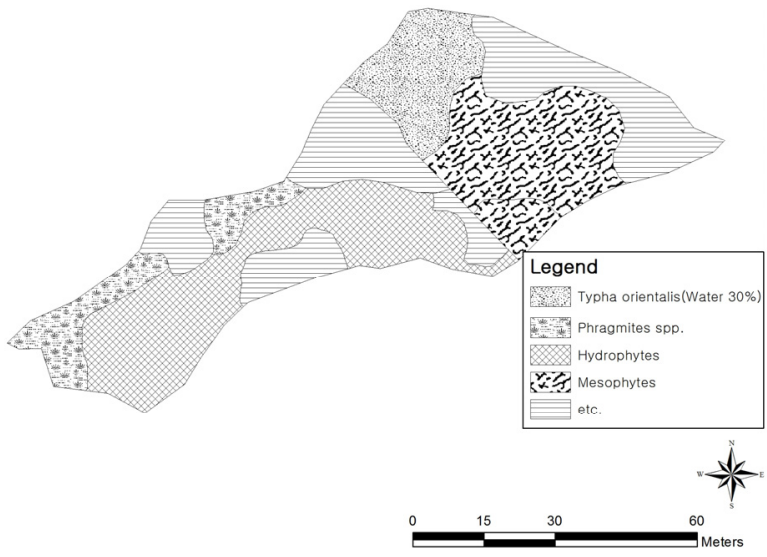

Ecotone type B 2015

Figure 2. Actual vegetation map by wetland type in 2012 and 2015. (Continued)

temporarily created. The pool type wetland increased as bare grounds dominated by mesophytes such as Artemisia princeps and Setaria viridis were restored into wetlands. The water surface area of the wetlands of ecotone type A and B were reduced from $7.2 \%$ in 2012 to $3.0 \%$ in 2015 , which is attributed to the phenomenon that Phragmites australis was spread across the water surface and neighboring areas. The water surface of the ecotone type B wetland was reduced from $2.9 \%$ to $2.3 \%$, which is attributable to transition to the ground caused by their shallow water depth $(0.2 \mathrm{~m})$. However, since it is located near the edges of mountains, vegetation disturbance is continuously caused by wild animals, especially boars, which delayed the reduction of the water surface of the wetlands.

Based on the results, it can be concluded that the shallow part of constructed wetlands was continuously dominated by emergent plants such as Typha orientalis, Phragmites australis, Phragmites japonica and Leersia japonica over time, which reduced the water surface, and the results can be attributed to transition as Whisenant (1999) and Weller (1999) pointed out. Still, in some cases of the ecotone type wetlands, natural disturbance caused by boars delayed the process of drying and terrestrialization, but the trend of decreasing water surface continued to be observed.

\section{Changes in the characteristics of fauna}

\section{Wild birds}

Table 4 shows the number, population and diversity of the wild birds observed in each wetland type. The number and population of species in the deep, medium and shallow water wetlands increased from 6, 5 and 4 species in 2012 to 13,10 
Table 4. Changes in wild birds species, population, and diversity by wetland type

\begin{tabular}{|c|c|c|c|c|c|c|c|}
\hline \multirow[b]{2}{*}{ Type } & \multicolumn{3}{|c|}{2012} & \multicolumn{3}{|c|}{2015} & \multirow[b]{2}{*}{ Dominant species } \\
\hline & $\begin{array}{l}\text { Number of } \\
\text { species }\end{array}$ & Population & $\begin{array}{l}\text { Diversity } \\
\text { index }\end{array}$ & $\begin{array}{l}\text { Number of } \\
\text { species }\end{array}$ & Population & $\begin{array}{l}\text { Diversity } \\
\text { index }\end{array}$ & \\
\hline $\begin{array}{l}\text { Deep water } \\
\text { wetland }\end{array}$ & 6 & 12 & 1.79 & 13 & 36 & 2.10 & $\begin{array}{c}\text { Paradoxornis webbianus, Anas } \\
\text { poecilorhyncha, Streptopelia orientalis }\end{array}$ \\
\hline $\begin{array}{l}\text { Medium water } \\
\text { wetland }\end{array}$ & 5 & 8 & 1.56 & 10 & 26 & 2.07 & $\begin{array}{c}\text { Pica pica sericea, Anas poecilorhyncha, } \\
\text { Egretta alba modesta }\end{array}$ \\
\hline $\begin{array}{l}\text { Shallow water } \\
\text { wetland }\end{array}$ & 4 & 36 & 1.39 & 10 & 49 & 1.86 & $\begin{array}{l}\text { Paradoxornis webbianus, Anas crecca } \\
\text { Linnaeus, Aegithalos caudatusmagnus }\end{array}$ \\
\hline $\begin{array}{l}\text { Non-cultivated } \\
\text { type }\end{array}$ & 5 & 18 & 1.30 & 4 & 23 & 1.33 & $\begin{array}{c}\text { Paradoxornis webbianus, Cyanopica cyana, } \\
\text { Streptopelia orientalis }\end{array}$ \\
\hline Pool type & 2 & 2 & 0.69 & 10 & 47 & 1.98 & $\begin{array}{c}\text { Cyanopica cyana, Anas crecca Linnaeus, } \\
\text { Pica pica sericea }\end{array}$ \\
\hline Ecotone type A & 10 & 24 & 2.23 & 18 & 122 & 2.33 & $\begin{array}{c}\text { Paradoxornis webbianus, Veratrum } \\
\text { oxysepalum Turcz, Streptopelia orientalis }\end{array}$ \\
\hline Ecotone type B & 7 & 63 & 1.81 & 14 & 56 & 2.45 & $\begin{array}{l}\text { Paradoxornis webbianus, Microscelis } \\
\text { amaurotis, Veratrum oxysepalum Turcz }\end{array}$ \\
\hline
\end{tabular}

and 10 species in 2015 . The number of species in the non-cultivated wetland decreased from 5 species to 4 species, but their population increased. The pool type wetland was increased from 2 species ( 2 individuals) to 10 species (47 individuals), which can be attributed to the expanded area of water surface and hydrophytes. In the case of ecotone type A, the number and population of species increased from 10 species and 24 individuals in 2012 to 18 species and 122 individuals in 2015, and in the case of ecotone type B, those of species increased from 7 species and 63 individuals to 14 species and 56 individuals. In wetlands that maintain water surface such as the deep, medium and shallow water wetlands and the pool type wetland, water birds such as Anas poecilorhyncha and Anas crecca, and bush type birds that live in Phragmites australis and Typha orientalis such as Sinosuthora webbiana were observed. On the contrary, mountain birds such as Parus major, Hypsipetes amaurotis and Streptopelia orientalis were found to dominate the ecotone type wetlands.

The highest number and population of wild birds were observed in the ecotone type wetlands, which seems to be caused by species introduced from neighboring ecosystems such as mountain birds from forests and water birds from farmlands (Weller, 1999). The number and population of species in the pool type wetland increased the most, which is attributable to the fact that the potential habitat for water birds such as water surface was expanded in 2015 compared to 2012. However, there was no significant change in the composition of vegetation and physical structures of the non-cultivated wetland.

\section{Herptiles}

Table 5 shows the status of amphibians and reptiles observed in each wetland between April and December 2015. In the ecotone type A wetland, 5 species including Hynobius leechii Boulenger, Bombina orientalis and Hyla japonica Gunther and their eggs were observed. In the case of Hynobius leechii Boulenger, the metamorphosis process of turning fertilized eggs to adults occurs in aquatic environments, which gives significant implications to studies on biodiversity (Boyer and Grue, 1995). In each of the deep and medium water wetlands and the pool type wetland, 4 species were observed, while only one species (Rana nigromaculata Hallowell) was observed in the non-cultivated wetland. In the presence of water surface, the amount of water inflowing from the outside is constant and the water surface is maintained, while the 
Table 5. Observation status of herptile adult $(\bullet)$ and spawn (○) by wetland type

\begin{tabular}{|c|c|c|c|c|c|c|c|c|c|c|c|c|c|c|}
\hline \multirow{2}{*}{ Scientific name } & \multicolumn{2}{|c|}{$\begin{array}{l}\text { Deep water } \\
\text { wetland }\end{array}$} & \multicolumn{2}{|c|}{$\begin{array}{c}\text { Medium water } \\
\text { wetland }\end{array}$} & \multicolumn{2}{|c|}{$\begin{array}{c}\text { Shallow water } \\
\text { wetland }\end{array}$} & \multicolumn{2}{|c|}{$\begin{array}{l}\text { Non-cultivated } \\
\text { type }\end{array}$} & \multicolumn{2}{|c|}{ Pool type } & \multicolumn{2}{|c|}{$\begin{array}{l}\text { Ecotone } \\
\text { type A }\end{array}$} & \multicolumn{2}{|c|}{$\begin{array}{l}\text { Ecotone } \\
\text { type B }\end{array}$} \\
\hline & adult & spawn & adult & spawn & adult & spawn & adult & spawn & adult & spawn & adult & spawn & adult & spawn \\
\hline Hynobius leechii Boulenger & - & - & - & - & - & - & - & - & - & - & ○ & $\bigcirc$ & - & - \\
\hline Bombina orientalis & - & - & - & - & - & - & - & - & 0 & - & - & - & - & - \\
\hline Hyla japonica Günther & - & - & $\bullet$ & - & - & - & - & - & - & - & - & - & - & - \\
\hline Rana amurensis Boulenger & - & - & $\bullet$ & $\bigcirc$ & $\bullet$ & $\bigcirc$ & - & - & $\bullet$ & $\bigcirc$ & $\bullet$ & $\bigcirc$ & 0 & $\bigcirc$ \\
\hline Rana dybowskii Günther & - & - & - & - & - & - & - & - & - & - & - & - & - & - \\
\hline Rana nigromaculata Hallowell & 0 & - & ○ & - & 0 & - & 0 & - & 0 & - & 0 & - & 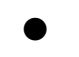 & - \\
\hline Rana catesbeiana Shaw & 0 & - & - & - & - & - & - & - & - & - & - & - & - & - \\
\hline Takydromus wolteri Fisher & 0 & - & - & - & - & - & - & - & - & - & - & - & - & - \\
\hline Rhabdophis tigrinus tigrinus & 0 & - & - & - & - & - & - & - & - & - & - & - & - & - \\
\hline Elaphe dione & - & - & $\bullet$ & - & - & - & - & - & - & - & - & - & - & - \\
\hline Elaphe rufodorsata & - & - & - & - & - & - & - & - & 0 & - & - & - & - & - \\
\hline
\end{tabular}

non-cultivated wetland had high density vegetation underneath the surface of water, and did not create a water surface except rainy season, which was not suitable for the habitation of amphibians.

\section{Butterflies}

The number of butterflies that were observed annually was counted (Table 6), and it was found that the diversity index of the deep, medium and shallow water wetlands was 1.61 ( 6 species, 54 individuals), 1.48 ( 5 species, 8 individuals) and 1.50 ( 5 species, 13 individuals) in 2012, and 1.45 (7 species, 28 individuals), 1.52 (6 species, 11 individuals) and 1.33 (4 species, 6 individuals) in 2015. The number increased in 2015 compared to 2012, but diversity was similar or decreased. The diversity index of the non-cultivated and pool type wetland increased from 1.36 (4 species, 32 individuals) and 1.10 ( 3 species, 3 individuals) in 2012 to 1.43 ( 5 species, 9 individuals), 1.61 (5 species, 6 individuals) in 2015 . The diversity index of the ecotone type A and B increased from 1.89 ( 8 species, 34 individuals) and 1.56 (5 species, 14 individuals) in 2012 to 2.12 (11 species, 29 individuals) and 2.07 (9 species, 36 individuals) in 2015, which can be attributed to the fact

Table 6. Changes in butterfly species, population, and diversity by wetland type

\begin{tabular}{|c|c|c|c|c|c|c|c|}
\hline \multirow[b]{2}{*}{ Type } & \multicolumn{3}{|c|}{2012} & \multicolumn{3}{|c|}{2015} & \multirow[b]{2}{*}{ Dominant species } \\
\hline & $\begin{array}{l}\text { Number of } \\
\text { species }\end{array}$ & Population & $\begin{array}{c}\text { Diversity } \\
\text { index }\end{array}$ & $\begin{array}{c}\text { Number of } \\
\text { species }\end{array}$ & Population & $\begin{array}{c}\text { Diversity } \\
\text { index }\end{array}$ & \\
\hline Deep water wetland & 6 & 54 & 1.61 & 7 & 28 & 1.45 & Everes argiades \\
\hline Medium water wetland & 5 & 8 & 1.48 & 6 & 11 & 1.52 & Polygonia caureum \\
\hline Shallow water wetland & 5 & 13 & 1.50 & 4 & 6 & 1.33 & Everes argiades \\
\hline Non-cultivated type & 4 & 32 & 1.36 & 5 & 9 & 1.43 & Everes argiades \\
\hline Pool type & 3 & 3 & 1.10 & 5 & 6 & 1.61 & Polygonia caureum \\
\hline Ecotone type A & 8 & 34 & 1.89 & 11 & 29 & 2.12 & Polygonia caureum \\
\hline Ecotone type B & 5 & 14 & 1.56 & 9 & 36 & 2.07 & Everes argiades \\
\hline
\end{tabular}


that they are neighbored with various ecosystems such as forests and farmlands (Gilbert and Anderson, 2004). This means that a variety of vegetation essential for the habitation of butterflies is distributed as a source of feed. Everes argiades and Polygonia caureum were observed in the medium and shallow water wetlands, the non-cultivated wetland and the ecotone type wetlands, and Everes argiades and Celastrina argiolus were observed in the deep water wetland. Polygonia caureum and Colias erate were observed in the pool type wetland.

There was no significant difference in the number and population of species between 2012 and 2015 in all the wetlands except the ecotone type wetlands. Since butterflies live on plants (Kim and Kang, 2011), the diversity of plants is very important for the growth of butterflies as a source of feed, but there seem to be physical limitations and the high prevalence of a single species such as Typha orientalis and Phragmites australis.

\section{Dragonflies}

The number of dragonflies that were observed was counted (Table 7). The diversity index of the deep and medium water wetlands increased from 2.04 ( 21 species, 1,687 individuals) and 1.95 (16 species, 1,286 individuals) in 2012 from 2.56 (19 species, 246 individuals) and 1.99 (16 species, 417 individuals) in 2015, while the shallow water wetland decreased from 2.12 (15 species, 1,324 individuals) in 2012 to 1.78 (12 species, 277 individuals) in 2015. In overall, there was no significant change in the number of species, but their population sharply decreased, which can be attributed to the spread of a single species such as Typha orientalis and Phragmites australis and a decrease in habitat diversity such as the reduced area of water surface (Federico and Kandasamy, 2008). While the diversity index of the non-cultivated wetland decreased from 1.90 ( 8 species, 58 individuals) in 2012 to 1.63 (7 species, 58 individuals) in 2015, that of the pool type wetland increased from 1.91 (10 species, 167 individuals) in 2012 to 2.26 (15 species, 260 individuals) in 2015. The ecotone types A and B decreased from 2.10 (18 species, 208 individuals) and 1.95 (11 species, 112 individuals) in 2012 to 1.93 (11 species, 194 individuals) and 1.82 (11 species, 496 individuals) in 2015.

Changes in the number and population of major species were examined by the type of wetlands (Table 7), and Ischnura asiatica was mainly observed in the deep and shallow water wetlands, the non-cultivated wetland, and the pool type wetland. Ischnura senegalensis was observed in the medium water wetland, and Coenagrion johanssoni was observed in the ecotone type wetlands. The wetlands of which water surface significantly changed except the ecotone type, noncultivated and pool type wetlands showed a significant decrease in the population of major species (only $5 \%$ of the population in 2012 was observed in 2015). These results are similar to the suggestion of Weller and Spatcher (1965) that a

Table 7. Changes in dragonfly species, population, and diversity by wetland type

\begin{tabular}{|c|c|c|c|c|c|c|c|c|c|}
\hline \multirow[b]{2}{*}{ Type } & \multicolumn{3}{|c|}{2012} & \multicolumn{3}{|c|}{2015} & \multicolumn{3}{|c|}{ Population change of dominant species } \\
\hline & $\begin{array}{l}\text { Number } \\
\text { of species }\end{array}$ & Population & $\begin{array}{c}\text { Diversity } \\
\text { index }\end{array}$ & $\begin{array}{l}\text { Number } \\
\text { of species }\end{array}$ & Population & $\begin{array}{c}\text { Diversity } \\
\text { index }\end{array}$ & Dominant species & 2012 & 2015 \\
\hline Deep water wetland & 21 & 1,687 & 2.04 & 19 & 246 & 2.56 & Ischnura asiatica & 1,442 & 84 \\
\hline Medium water wetland & 16 & 1,286 & 1.95 & 16 & 417 & 1.99 & Ischnura senegalensis & 1,228 & 12 \\
\hline Shallow water wetland & 15 & 1,324 & 2.12 & 12 & 277 & 1.78 & Ischnura asiatica & 1,260 & 33 \\
\hline Non-cultivated type & 8 & 58 & 1.90 & 7 & 58 & 1.63 & Ischnura asiatica & 33 & 5 \\
\hline Pool type & 10 & 167 & 1.91 & 15 & 260 & 2.26 & Ischnura asiatica & 121 & 117 \\
\hline Ecotone type A & 18 & 208 & 2.10 & 11 & 194 & 1.93 & Coenagrion johanssoni & 121 & 175 \\
\hline Ecotone type B & 11 & 112 & 1.95 & 11 & 496 & 1.82 & Coenagrion johanssoni & 66 & 426 \\
\hline
\end{tabular}


decrease in habitat diversity, such as the decreased area of water surface caused by the increased vegetation density and coverage ratio, affects the number and population of species. Changes in the number and population of species in the pool type wetland can be attributed to its water surface expanded by restoring the area which was previously dominated by mesophytes.

\section{Trend of changes in biodiversity}

Table 8 shows the trend of changes in biodiversity before and after constructing wetlands. The water surface of the deep water wetland was reduced by about $14 \%$ from $25.5 \%\left(1,324.3 \mathrm{~m}^{2}\right)$ to $11.9 \%\left(617.8 \mathrm{~m}^{2}\right)$ due to the spread of Typha orientalis and Phragmites australis, but its water depth was maintained within the range of $5.3 \sim 111.1 \mathrm{~cm}$. In terms of biodiversity of each fauna, the biodiversity index of wild birds increased $(1.79 \rightarrow 2.10)$, while that of butterflies decreased $(1.61 \rightarrow 1.45)$. The biodiversity of dragonflies increased $(2.04 \rightarrow 2.56)$, which is attributable to the decrease in the population of species rather than the number of species. The water surface of the medium water wetland was reduced by about $19 \%$ from $36.2 \%\left(982.1 \mathrm{~m}^{2}\right)$ to $11.8 \%\left(470.3 \mathrm{~m}^{2}\right)$ as plants such as Typha orientalis, Leersia Japonica, etc. were spread and covered its shallow area. The species diversity of wild birds $(1.56 \rightarrow 2.07)$, butterflies $(1.48 \rightarrow 1.52)$ and dragonflies $(1.95 \rightarrow 1.99)$ increased. While the number of wild bird and butterfly species increased, there was no change in the number of dragonfly species (16 species), but the decrease in the population of dragonfly species $(1,286 \rightarrow 417)$ resulted in the increase in the species diversity. The decreased water surface of the medium water wetland also seems to decrease the number of species, which is similar to the results of an earlier study that the horizontal or vertical decrease in diversity in habitats results in the decrease in species diversity (Weller, 1979). Since the water depth of the shallow water wetland is $11.5 \sim 35 \mathrm{~cm}$, its water surface decreased from $15.5 \%\left(411.9 \mathrm{~m}^{2}\right)$ in 2012 to $0.9 \%\left(24.0 \mathrm{~m}^{2}\right)$ in 2015 due to the spread of Typha orientalis, Leersia Japonica, etc. This resulted in the decrease in habitat diversity. The species diversity of wild birds increased $(1.39 \rightarrow 1.86)$, but that of butterflies $(1.50 \rightarrow 1.33)$ and dragonflies $(2.12 \rightarrow 1.78)$ decreased, which can be attributed, particularly, to the about $90 \%$ decrease in the population of dragonflies in 2015, compared to 2012.

The non-cultivated wetland had no water surface in 2012, but, in 2015, the puddles that had a water depth of $4 \sim 12 \mathrm{~cm}$ accounted for $15.5 \%\left(418.8 \mathrm{~m}^{2}\right)$. The species diversity of wild birds $(1.30 \rightarrow 1.33)$ and butterflies $(1.36 \rightarrow 1.43)$ increased, while that of dragonflies decreased $(1.90 \rightarrow 1.63)$, which is attributable to the decrease in the number of species. The water depth of the pool type wetland varied from $0.5 \mathrm{~cm}$ to $59 \mathrm{~cm}$, but its water surface increased by about $29 \%$ from $6.8 \%$ $\left(329.6 \mathrm{~m}^{2}\right)$ in 2012 to $35.6 \%\left(1,023.2 \mathrm{~m}^{2}\right)$ in 2015 . The species diversity of wild birds $(0.69 \rightarrow 1.98)$, butterflies $(1.10 \rightarrow$

Table 8. Change of ecosystem and biodiversity

\begin{tabular}{|c|c|c|c|c|c|c|c|c|c|c|c|c|c|c|c|}
\hline \multirow{2}{*}{ Classification } & \multirow{2}{*}{ Legend } & \multicolumn{2}{|c|}{$\begin{array}{l}\text { Deep water } \\
\text { wetland }\end{array}$} & \multicolumn{2}{|c|}{$\begin{array}{l}\text { Medium water } \\
\text { wetland }\end{array}$} & \multicolumn{2}{|c|}{$\begin{array}{c}\text { Shallow water } \\
\text { wetland }\end{array}$} & \multicolumn{2}{|c|}{$\begin{array}{l}\text { Non-cultivated } \\
\text { type }\end{array}$} & \multicolumn{2}{|c|}{ Pool type } & \multicolumn{2}{|c|}{ Ecotone type A } & \multicolumn{2}{|c|}{ Ecotone type B } \\
\hline & & 2012 & 2015 & 2012 & 2015 & 2012 & 2015 & 2012 & 2015 & 2012 & 2015 & 2012 & 2015 & 2012 & 2015 \\
\hline \multirow{2}{*}{ Open water } & Area $\left(\mathrm{m}^{2}\right)$ & $1,324.3$ & 617.8 & 982.1 & 525.3 & 411.9 & 24.0 & - & 418.1 & 329.6 & $1,023.2$ & 234.8 & 99.0 & 195.0 & 154.7 \\
\hline & Percent (\%) & 25.5 & 11.9 & 36.2 & 19.4 & 15.5 & 0.9 & - & 15.4 & 6.8 & 35.6 & 7.2 & 3.0 & 2.9 & 2.3 \\
\hline Water depth & $\mathrm{cm}$ & \multicolumn{2}{|c|}{$5.3 \sim 111.1$} & \multicolumn{2}{|c|}{$23 \sim 43.3$} & \multicolumn{2}{|c|}{$11.5 \sim 35$} & \multicolumn{2}{|c|}{$4 \sim 12$} & \multicolumn{2}{|c|}{$5 \sim 59$} & \multicolumn{2}{|c|}{$1 \sim 58$} & \multicolumn{2}{|c|}{$1.5 \sim 13.5$} \\
\hline Wild birds & diversity & 1.79 & 2.10 & 1.56 & 2.07 & 1.39 & 1.86 & 1.30 & 1.33 & 0.69 & 1.98 & 2.23 & 2.33 & 1.81 & 2.45 \\
\hline Butterflies & diversity & 1.61 & 1.45 & 1.48 & 1.52 & 1.50 & 1.33 & 1.36 & 1.43 & 1.10 & 1.61 & 1.89 & 2.12 & 1.56 & 2.07 \\
\hline Dragonflies & diversity & 2.04 & 2.56 & 1.95 & 1.99 & 2.12 & 1.78 & 1.90 & 1.63 & 1.91 & 2.26 & 2.10 & 1.93 & 1.95 & 1.82 \\
\hline Herptile & population & - & 4 & - & 4 & - & 2 & - & 1 & - & 4 & - & 5 & - & 2 \\
\hline
\end{tabular}


$1.61)$ and dragonflies $(1.91 \rightarrow 2.26)$ increased, which can be attributed to the increase in both the number and population of species.

The water surface of the ecotone type A wetland decreased by about 4\% from $7.2 \%$ in 2012 to $3.0 \%$ in 2015 , which can be attributed to the spread of Phragmites japonica and Phragmites australis across the shallow water surface $(1 \sim 58 \mathrm{~cm})$. The species diversity of wild birds $(2.23 \rightarrow 2.33)$ and butterflies $(1.89 \rightarrow 2.12)$ increased, while that of dragonflies decreased from 2.10 to 1.93 , which can be attributed to the decrease in the number (18 species $\rightarrow 11$ species) and population (208 individuals $\rightarrow 194$ individuals) of species. The water surface of the ecotone type $\mathrm{B}$ wetland was reduced by about $1 \%$ from $4.1 \%$ in 2012 to $3.1 \%$ in 2015, which can be attributed to the spread of Typha orientalis across the shallow water surface $(1.5 \sim 13.5 \mathrm{~cm})$. While the species diversity of wild birds $(1.81 \rightarrow 2.45)$ and butterflies $(1.56 \rightarrow 2.07)$ increased, that of dragonflies decreased from 1.95 to 1.82 , which can be attributed to the increase in the population of species.

The water surface of all the wetlands except the non-cultivated and pool type wetlands decreased in 2015 compared to that in 2012. The decrease seems to be caused by the spread of not only Typha orientalis and Phragmites japonica that were planted originally but also Leersia Japonica that was moved from the outside across their shallow area over time. The reduced water surface of wetlands and coverage by a single species were reported to decrease habitat diversity but also biodiversity (Weller, 1999; France, 2003). Wild birds and butterflies can be introduced from other ecosystems, but water is essential for wetland dependent species such as dragonflies to lay eggs and keep their larvae survive (Corbet, 1999). However, the spread of vegetation across shallow areas decreases not only habitat diversity (Knight, 1997; Weller, 1979) but also the population of dragonflies, wetland dependent species, which raises the importance of controlling the phenomenon. In the case of the ecotone type B wetland, however, there was almost no change observed compared to the past, which was the result of the continuous disturbance of inner vegetation caused by wild animals, especially boars due to its locational characteristics. Likewise, the decrease in the water surface within wetlands continued to be observed in most wetlands, which is expected to affect the diversity of species that live in wetlands.

\section{Measures to create and manage constructed wetlands}

Table 9 shows the trend of changes in habitat and species diversity by the type of wetlands. Except the non-cultivated and pool type wetlands, the vegetation of the rest wetlands was simplified and their water surface was also reduced. There was no change in vegetation in the non-cultivated wetland, which can be attributed to the temporary creation of water surface when it rained, but the water surface of the pool type wetland increased as its neighboring bare grounds were

Table 9. Ecosystem characteristics and species changes by wetland type

\begin{tabular}{|c|c|c|c|c|c|}
\hline \multirow{2}{*}{ Classification } & \multicolumn{2}{|c|}{ Ecological characteristics } & \multicolumn{3}{|c|}{ Fauna } \\
\hline & Vegetation coverage & Open water & Wildbird & Butterfly & Dragonfly \\
\hline Deep water wetland & Increase $(\triangle)$ & Decrease $(\nabla)$ & Increase $(\triangle)$ & Increase $(\triangle)$ & Decrease $(\nabla)$ \\
\hline Medium water wetland & Increase $(\triangle)$ & Decrease $(\nabla)$ & Increase $(\triangle)$ & Increase $(\triangle)$ & Decrease $(\nabla)$ \\
\hline Shallow water wetland & Increase $(\triangle)$ & Decrease $(\boldsymbol{\nabla})$ & Increase $(\triangle)$ & Decrease $(\boldsymbol{\nabla})$ & Decrease $(\boldsymbol{\nabla})$ \\
\hline Non-cultivated type & Decrease $(\nabla)$ & Increase $(\triangle)$ & Decrease $(\nabla)$ & Increase $(\triangle)$ & Decrease $(\nabla)$ \\
\hline Pool type & Decrease $(\nabla)$ & Increase $(\triangle)$ & Increase $(\triangle)$ & Increase $(\triangle)$ & Increase $(\triangle)$ \\
\hline Ecotone type A & Increase $(\triangle)$ & Decrease $(\boldsymbol{\nabla})$ & Increase $(\triangle)$ & Increase $(\triangle)$ & Decrease $(\boldsymbol{\nabla})$ \\
\hline Ecotone type B & Increase $(\triangle)$ & Decrease $(\nabla)$ & Increase $(\triangle)$ & Increase $(\triangle)$ & Increase $(\triangle)$ \\
\hline
\end{tabular}


turned into wetlands. In the case of the deep, medium and shallow water wetlands and the ecotone type A wetland, their ground was covered by Miscanthus sacchariflorus, their water surface, by Phragmites australis, Phragmites japonica, Typha orientalis, etc. across their shallow area, which decreased their water surface and simplified their vegetation. Exceptively, the water surface of the ecotone type B wetland in 2015 was similar to that in 2012, which can be attributed to the puddles maintained by the continuous disturbance of wild animals, particularly boars due to its locational characteristics.

Changes in the species diversity of wild birds and butterflies seem to be caused by the increasing number of species introduced from the outside in ecological environments that were stabilized over time such as vegetation and the structure of wetlands. The number and population of butterflies were reduced in most of the surveyed wetlands except the pool type and ecotone type B wetlands. In particular, the number and population of species in the deep, medium and shallow water wetlands and the ecotone type A wetland was significantly reduced, which can be attributed to the noticeable decrease in their water surface in 2015 compared to 2012. The water surface ratio decreased by $4 \% \sim 19 \%$, which seems to have the highest impact on the habitat density for dragonflies.

This study monitored time series changes in the biotas of the wetlands that were divided based on their locational characteristics and water depth, and the conditions of their neighboring natural environments, and it was found that the ecotone type wetlands surrounded by various ecosystems such as forests and farmlands had a higher species diversity than other types. The results seem to be highly related to the increasing available habitat and sources of feed (Knight, 1997). The water surface of the constructed wetlands was reduced as hragmites australis and Typha orientalis that were originally planted and Leersia Japonica that was naturally introduced from the outside were spread across their shallow area of which water depth was $1.1 \mathrm{~m}$ or lower. The shallow water depth of constructed wetlands accelerates the growth of a single species, which was reported to reduce the diversity of animal species (Weller, 1999). In the wetlands surveyed in this study, there was no significant difference in wild birds and butterflies that can be introduced from the outside, but the population of dragonflies, wetland dependent species, sharply decreased, which indicates the importance of securing the sufficient water surface of shallow areas.

When creating or restoring constructed wetlands in the future, it will be necessary to select their locations and maintain an water surface by controlling water depth. It is recommended to choose the locations of new constructed wetlands among places that are neighbored with various ecosystems in order to expect the natural introduction of species from the outside (Knight, 1997). In addition, since it is necessary to supply water smoothly to wetlands, it is essential to select places that can supply water (DuPoldt et al., 2015). It was also reported that water depth needs to be maintained below $1 \mathrm{~m}$ $(0.1 \sim 0.5 \mathrm{~m})$ in order to maintain the distribution of various vegetation when creating and restoring wetlands, and that water depth needs to be maintained between $2 \mathrm{~m}$ and $3 \mathrm{~m}$ to secure a certain area of water surface and thus to maintain habitat diversity (Alberta Government, 2014). Since aquatic plants can not grow in areas of which water depth is over $3 \mathrm{~m}$, it is necessary to maintain water depth in order to secure water surface, but at least a water depth of $1 \sim 2 \mathrm{~m}$ needs to be maintained (Gilbert and Anderson, 2004). Water depth is also an important factor for improving the biodiversity of aquatic ecosystems. Although the desired water depth for each dragonfly differs, Koo and Sim (1997) suggested to maintain water depth at 50 100 cm in deep areas and 10 30 cm in shallow areas. Small-sized wetlands are also important as habitat for dragonflies (Corbet, 1999), and thus it is necessary to secure a certain size of water surface in order to ensure they find the wetlands in the air. Therefore, it is recommended to select places with a water depth of $1 \mathrm{~m}$ or less for vegetation, and places with a water depth of $2 \sim 3 \mathrm{~m}$ for maintaining water surface, and thus to maintain various contour lines.

Meanwhile, constructed or restored wetlands should be self-sustaining and perform various ecological functions, which 
requires long-term maintenance and management (Alberta Government, 2014). In addition, various contour lines should be maintained, and watersides should be created in an irregular shape in order to maintain wildlife diversity (Dupoldt et al., 2015). In terms of habitat diversity, if constructed wetlands are covered by a single species due to their shallow water depth, their biodiversity can be reduced (Knight, 1997). Therefore, it will be necessary to manage vegetation in order to maintain water surface. Still, water, that is, water surface plays the biggest role in the influx of wild animals when creating wetlands, and France (2003) suggested to maintain water surface at 50\% in order to increase or maintain the diversity of animal species. The results of this study show that the area of water surface and the number of wetland dependent species were reduced over time after creating wetlands, which requires maintenance and management (Craft, 2016). In general, the time required to monitor each index differs, but Mattews et al. (2009) pointed out that management plans need to be suggested based on the results of long-term observation for $5 \sim 10$ years. In order to maintain water surface based on the results of sufficiently monitoring, maintenance measures, such as adjusting water depth and controlling the spread of plant communities are required.

\section{Conclusions}

The Korean government has designated the areas that are within $0.5 \sim 1 \mathrm{~km}$ from river and lake boundaries as a riparian buffer zone for improving the water quality of the four major rivers and has purchased buildings that directly affect the water quality management of water supply sources such as factories, cattle sheds and restaurants since 2003. In the purchased land, ecological belts for goals such as restoring wetlands and vegetation have been constructed in order to treat pollutants, which is expected to promote the role of buffer green zones and biodiversity. So far, approximately $14.5 \mathrm{~km}^{2}$ of land has been purchased, and $41.4 \%\left(6.0 \mathrm{~km}^{2}\right)$ of the land was turned into constructed wetlands and forest vegetation. This study monitored the physical environments and fauna of constructed wetlands with different sizes, shapes, water depth and plant coverage in Sancheong-gun, Korea, and suggested measures to create and manage constructed wetlands. To do so, this study was conducted following the three stages: surveying and analyzing the physical environments and ecological characteristics of constructed wetlands; assessing biodiversity; and suggesting measures to create and manage wetlands.

First, the trend of changes in habitat by the type of wetlands was examined, and it was found that except the non-cultivated and pool type wetlands, the vegetation of the rest wetlands was simplified and their water surface was also reduced over time. There was no change in vegetation in the non-cultivated wetland, which can be attributed to the temporary creation of water surface when it rained. The water surface of the pool type wetland increased as its neighboring bare grounds were turned into wetlands. In the case of the deep, medium and shallow water wetlands and the ecotone type A wetland, their ground was covered by Miscanthus sacchariflorus, their water surface, by Phragmites australis, Phragmites japonica, Typha orientalis, etc. across their shallow areas, which decreased their water surface and simplified their vegetation. Therefore, the management of vegetation and water depth needs to be considered from the early stage of creating wetlands. Exceptively, the water surface of the ecotone type wetlands in 2015 was similar to that in 2012, which can be attributed to the puddles maintained by the continuous disturbance of wild animals, particularly boars due to its locational characteristics. Changes in the species diversity of wild birds and butterflies seem to be caused by the increasing number of species introduced from the outside in ecological environments that were stabilized over time such as vegetation and the structure of wetlands. The number and population of butterflies were reduced in most of the surveyed wetlands except the pool type and ecotone type B wetlands. In particular, the number and population of species in the deep, medium and shallow water wetlands and the ecotone type A wetland was significantly reduced, which can be attributed to the noticeable decrease in their water surface in 2015 compared to 2012 . The water surface ratio decreased by 
$4 \% \sim 19 \%$, which seems to have the highest impact on habitat density for dragonflies.

Based on the results of monitoring various types of wetlands, measures to create and manage wetlands for the promotion of biodiversity were suggested. First, in selecting locations for restoration, it is essential to preferentially purchase lands that are neighbored with various ecosystems such as fields and paddies, and rivers to which water can be naturally supplied. The results of surveys and analysis in this study showed that the species diversity of constructed wetlands that were neighbored with forests and farmlands, rather than those that were created within farmlands was relatively high, which coincides with the suggestion of Knight (1997) that pointed out that it is better to construct wetlands being neighbored with various ecosystems. Second, it was analyzed that the water surface of the constructed and restored wetlands was reduced as their shallow area (less than $1 \mathrm{~m}$ ) was covered by a single species within 3 years after being constructed. Thus, it is necessary to maintain the water depth of wetlands within less than $1 \mathrm{~m}(0.1 \sim 0.5 \mathrm{~m})$ in order to secure the diversity of aquatic plants and water surface, and to maintain the water depth of a certain space within $2 \sim 3 \mathrm{~m}$ in order to maintain water surface (Alberta Government, 2014; Gilbert and Anderson, 2004). Third, according to France (2003), the species diversity of wetland-dependent species including dragonflies can be maintained as they can find wetlands in the air only when water surface is maintained at over $50 \%$. In terms of maintenance and management measures, first, long-term management is required, which coincides with the suggestion of the Alberta Government (2014) that recommended to manage sediment and vegetation in the long term in order to maintain the self-control ability of constructed wetlands. Second, in order to maintain the diversity of wild animals and plants, it is necessary to maintain various contour lines, and to continuously manage wetlands, such as adjusting water depth and controlling the spread of plant communities. As a result, it can be concluded that it is essential to manage water surface by selecting proper locations and maintaining different water depths for the maintenance and management of the biodiversity of constructed wetlands.

Meanwhile, it was desirable to conduct this study based on the results of long-term observations for $5 \sim 10$ years, but the study could not been carried out for a long time, since many changes occurred in wetlands of which water depth was low. In addition, one of the original purposes of constructed wetlands is water purification. However, in the case of wetlands created within farmlands, the water quality of their inlet is often better than that of their outlet since no pollutant flows into the wetlands except busy farming season (April May), and thus it is not easy to verify their effects. In this regard, it seems to be necessary to realize other goals that can be obtained by restoring forest vegetation and wetlands such as promoting biodiversity and providing services for local residents. From the aspect of protecting the water quality of the four major rivers in Korea, if point and nonpoint pollution sources are purchased, it can result in the balloon effect of constructing cattle sheds and vinyl greenhouses in other regions, and thus it is also necessary to consider the maximization of the effectiveness of water purification by purchasing small-sized areas and areas that are neighbored with pollution sources. Meanwhile, since restoration effects that can be identified through short, medium and long-term monitoring can differ, maintenance and management measures need to be suggested based on the results of observations for $5 \sim 10$ years as Mattews et al. (2009) suggested.

\section{References}

Alberta Government. 2014. General design guidelines for a constructed 'Habitat' wetland - Grasslands natural region of Alberta. Retrieved from http://www.transportation.alberta.ca/Content/docType29/production/DGfCHW_Grasslands NaturalRegionofAlberta.pdf

Boyer, R. and C.E. Grue. 1995. The need for water quality criteria for frogs. Environ. Health Perspect. 103(4):352-357. 
Brix, H. 1997. Do macrophytes play a role in constructed treatment wetlands? Water Sci. Technol. 35(5):11-17. DOI: $10.1016 / \mathrm{S} 0273-1223(97) 00047-4$

Cho, B.Y. 2013. Study on the characteristics and improvement of habitat at the constructed wetlands on highway roadside : In case of constructed wetland, Gyeonggi-do, Korea. Master's thesis, University of Seoul, Korea.

Corbet, P.S. 1999. Dragonflies-Behavior and Ecology of Odonata. Ithaca, NY: Cornell University Press.

Cowardin, L.M., V. Carter, F.C. Golet, and E.T. LaRoe. 1979. Classification of Wetlands and Deepwater Habitats of the United States (FWS/OBS-79/31). Washington, DC: US Department of the Interior Fish and Wildlife service.

Craft, C. 2016. Creating and Restoring Wetlands: From Theory to Practice. Cambridge, MA: Elsevier.

Cylinder, P.D., K.M. Bogdan, E.M. Davis, and A. Herson. 1995. Wetlands Regulation: A Complete Guide to Federal and California Programs. Point Arena, CA: Solano Press Books.

DuPoldt, C., R. Edwards, L. Garber, B. Isaacs, J. Lapp, T. Murphy, G. Rider, M. Sayers, F. Suffian, C. Takita, and H. Webster. 2015. A Handbook of Constructed Wetlands: A guide to creating wetlands for agricultural wastewater, domestic wastewater, coal mine drainage, stormwater in the Mid-Atlantic region. Vol. 1 General considerations. Washington, DC: US Government Publishing Office.

Federico, R.D. and J. Kandasamy. 2008. Operation and Maintenance of Wetlands. In J. Kandasamy and S. Vigneswaran (Eds.), Constructed Wetlands (pp. 57-73). New York, NY: Nova Science Publishers.

France, R. L. 2003. Wetland Design: Principles and practices for Landscape Architects and Land-Use Planners. New York, NY: W.W. Norton \& Company.

Gilbert, O.L. and P. Anderson. 2004. Habitat Creation and Repair. New York, NY: Oxford university press.

Hiraishi, T., T. Krug, K. Tanabe, N. Srivastava, J. Baasansuren, M. Fukuda, and T.G. Troxler (Eds.). 2014. Supplement to the 2006 IPCC Guidelines for National Greenhouse Gas Inventories:Wetlands. Switzerland: IPCC.

Houghton, J.T., Y. Ding, D.J. Griggs, M. Noguer, P.J. van der Linden, X. Dai, K. Maskell, and C.A. Johnson (Eds.). 2001. Climate Change 2001: The Scientific Basis. Contribution of Working Group I to the Third Assessment Report of the Intergovernmental Panel on Climate Change. Cambridge, United Kingdom: Cambridge University Press.

Jones, K., Y. Lanthier, P. van der Voet, E. van Valkengoed, D. Taylor, and D. Fernández-Prieto. 2009. Monitoring and assessment of wetlands using earth observation: The GlobWetland project. J. Environ. Manag. 90(7):2154-2169. DOI:10.1016/j.jenvman.2007.07.037

Jung, K.S. 2007. Odonata of Korea. Seoul, Korea: Ilgongyuksa.

Kang, Y.S and I.B. Yoon. 1975. Illustrated Encyclopedia of Fauna \& Flora of Korea. Vol. 17 Amphibia-Reptilia. Seoul, Korea: Ministry of Education.

Keenleyside, K.A., N. Dudley, S. Cairns, C.M. Hall, and S. Stolton. 2012. Ecological Restoration for Protected Areas: Principles, Guidelines and Best Practices. Gland, Switzerland: IUCN.

Kim, H.C. 2010. Assessment of nonpoint source pollution reduction using constructed wetland . Doctoral dissertation. Konkuk university, Seoul, Korea.

Kim, J.S. and H.K. Kang. 2011. Analyzing mutual relationships between nectar plants and butterflies for landscape design -Focusing on World Cup Park, Seoul-. J. Korean Inst. Landsc. Archit. 39(1):11-21.

Kim, K.G. and D.K. Cho. 1999. The effects of the biodiversity increase after creation of the artificial wetland -The case of ecological pond at Seoul Technical High School-. J. Korean Inst. Landsc. Archit. 27(3):1-17.

Kim, K.J., J.S. Kim, I.H. Kim, and K.C. Yang. 2012. Characteristics of nutrient uptake by aquatic plant in constructed wetlands for treating livestock wastewater. J. Wetl. Res. 14(1):121-130.

Kim, M.J., S.D. Lee, and J.S. Kim. 2013. Selecting the optimal research time for forest birds census in each season. Korean J. Environ. Ecol. 7(2):219-229.

Kim, Y.R., J.L. Kim, K.S. Lee, K.J. Sung, and S.M. Lee. 2008. Performance comparison of a natural wetland and a constructed wetland for nonpoint pollutants control. J. Korean Soc. Water Qual. 2008:37-38 
Knight, R.L. 1997. Wildlife habitat and public use benefits of treatment wetlands. Water Sci. Technol. 35(5):35-43. DOI:10.1016/S0273-1223(97)00050-4

Koo, J.H. and W.K. Sim. 1997. Development of ecotechnology for the biotope creation in Korean rural area - With a special reference to Dragonfly Biotope - . J. Korean Inst. Landsc. Archit. 25(1):100-111.

Lee, S.H., L.H. Kim, and H.J. Cho. 2014. Analysis for removal efficiency of non-point pollution sources by constructed wetlands. Ecol. Resil. Infrastruct. 1(2):102-108.

Matthews, J.W., G. Spyreas, and A.G. Endress. 2009. Trajectories of vegetation-based indicators used to assess wetland restoration progress. Ecol. Appl. 19(8):2093-2107.

Ministry of Environment. 2012. Waterside ecological network planning report for the local community. Sejong, Korea: Author.

Ministry of Environment. 2018. 2008 waterside ecological network action planning. Sejong, Korea: Author.

Mitsch, W.J. and J.G. Gosselink. 2000. Wetlands (3rd ed.). Hoboken, NJ: John Wiley \& Sons.

Mitsch, W.J. and J.G. Gosselink. 2007. Wetlands (4th ed.). Hoboken, NJ: John Wiley \& Sons.

Moat, G., B. Simpson, P. Ghanem, J. Kandasamy, and S. Vigneswaran. 2008. Constructed Wetlands: Classification, Functions and Treatment. In J. Kandasamy and S. Vigneswaran (Eds.), Constructed Wetlands (pp. 1-26). New York, NY: Nova Science Publishers.

Moon, D.H., I.K. Lee, J.T. Kim, and S.O. Jang. 2014. Assessment of efficiency for constructed wetlands to reduced non-point source pollution. J. Korean Soc. Hazard Mitig. 14(1):333-340. DOI:10.9798/KOSHAM.2014.14.1.333

Rousseau, D.M., J. Manning, and D. Denyer. 2008. Evidence in management and organizational science: Assembling the field's full weight of scientific knowledge through syntheses. Acad. Manag. Ann. 2(1):475-515.

Seo, J.Y. 2014. Evaluation of combined vertical and horizontal flow sand-filled reed constructed wetland with intermittent feeding for sewage treatment. J. Wetl. Res. 16(2):261-268.

Shannon, C.E. and W. Weaver. 1949. The Mathematical Theory of Communication. Urbana, IL: University of Illinois press.

van der Valk, A.G. 2012. The Biology of Freshwater Wetlands (2nd ed.). New York, NY: Oxford university press.

Weller, M.W. 1979. Birds of some Iowa wetlands in relation to concepts of faunal preservation. Proc. Iowa Acad. Sci. 86(3):81-88.

Weller, M.W. 1999. Wetland Birds: Habitat Resources and Conservation Implications. Cambridge, UK: Cambridge university press.

Weller, M.W. and C.S. Spatcher. 1965. Role of Habitat in the Distribution and Abundance of Marsh Birds. Department of zoology and entomology, special report No. 43. Ames, IA: Iowa state university press.

Whisenant, S.G. 1999. Repairing Damaged Wildlands: A Process-Orientated, Landscape-scale Approach. Cambridge, UK: Cambridge university press.

Yang, S.Y., J.B. Kim, M.S. Min, J.H. Seo, and Y.J. Kang. 2001. Amphibians in Korea. Seoul, Korea: Academy press.

Zhu, W.H. and B.H. Koo. 2006. Wetlands classifying characteristics by wetlands classifying system -Cases on the Tu-men River and Han River-. J. Korea Soc. Environ. Restor. Reveg. Technol. 9(6):152-161. 